\title{
GENDER EQUALITY IN ISLAM AND GENDER BIASED DISCRIMINATION IN GLOBAL MUSLIM SOCIETIES: ANALYTIC AND CRITICAL EVALUATION
}

Syed Muhammad Shahid Tirmizi ${ }^{*}$, Abdul Rauf ${ }^{2}$, Iram Sultana $^{3}$, Muhammad Saeed ${ }^{4}$

${ }^{1 *}$ Assistant Professor, Bahria University Islamabad, Pakistan; ${ }^{2,3,4}$ Lecturer, National University of Modern Languages, Islamabad, Pakistan.

Email: ${ }^{1 *}$ stirmazi.buic@ @ahria.edu.pk, ${ }^{2}$ abrauf540@ gmail.com, ${ }^{3}$ isultana@numl.edu.pk, ${ }^{4}$ saeedtayab@gmail.com Article History: Received on $25^{\text {th }}$ March 2021, Revised on $14^{\text {th }}$ April 2021, Published on $1^{\text {st }}$ May 2021

\begin{abstract}
Purpose of the study: The main aim of this study is to stipulate the practical elucidation for the act in spotting sustaining ways of discrimination as well as inequality against the female children, obliterating ways, and practices that are harmful in fulfilling the rights of the females and prescribing an efficient policy for the protection and promotion of these rights.
\end{abstract}

Methodology: Analytical and critical evaluation techniques have been used in executing this research study. Ongoing gender-based discrimination in societies of Muslim worlds has been analysed through various sources including published journal articles, news articles, and books, etc. These analytical studies are then critically evaluated in the light of the Holy Quran and Sunnah as primary study resources.

Main Findings: Education helps in breaking the model of gender discrimination and creates permanent changes for the females in the developing states inclusive of Pakistan, among others. Pakistan has hardly invested in educational sectors, and specifically in the education of women. The education of girls leads to extensive social changes. Educated females are very significant to terminate this rapidly growing notion of gender discrimination.

Application of study: This study is applicable in the domain of gender studies in the perspective of global Islamic societies, in comprehension of the drawbacks of this norm faced by the societies, and the consequences of gender discrimination.

The novelty of this study: To the best of my knowledge this study explores the concept of gender inequality in the light of the Quran and Sunnah and gender discrimination in the society of Pakistan. Furthermore, it addresses the bill passed by the national assembly of Pakistan in context to the protection of Women's property rights in 2020 and its religious significances and advantages of observing this bill.

Keywords: Gender Discrimination, Gender Equality, Biasness, Education, Women Rights, Women Empowerment, Pakistan.

\section{INTRODUCTION}

The historical evidence depicts that the talents, as well as lives of many females, have been distorted and perverted because of this gender discrimination in numerous life aspects. In my personal thoughts regarding the uses and limitation of can-do tactics, comparison amidst gender discrimination and biasness have been found to be very useful. Several studies make use of these terminologies greater or lesser exchangeable, however, inequality among the genders comprises two somewhat dissimilar issues. Discrimination includes impediments to maximum contribution in human performances; biasness includes the cultural distinctiveness of the actions (Bukhari et al., 2019).

In the independent Western civilization, getting consensus upon the suggestion regarding discrimination being unfair is pretty straightforward. In this scenario, that female should be provided with the equivalent approach towards the professional benefits as well as opportunities to choose, build, and bring advancements in their careers and jobs. Achievement of the consensus regarding the proposal that the jobs together with the social life sciences are ethnically described as manly activities, also that this intrinsic biasness among the genders must be reworked. So far, the biasness among the genders in the societal sciences as well as the jobs, just in a similar way they are being practiced these days, is genuine, also, impediments to the maximum performance of the females will be presented continuously even in the case of ending of the gender discrimination.

In this study, the dual dimensions of gender discrimination will be discussed, particularly, in Pakistani society. For instance, if the males are provided with extensive vacations, improved reimbursement schemes, or increased rewards as compared to the females of the same society based upon the unjust gender biases, it is referred to as gender discrimination as well and would be considered illegal. Gender discrimination and gender biases are often exploited interchangeably, nevertheless, there exists some difference between the two. Gender biases are given with some priority towards specific sex, at times designated to be Sex biasness. Some people prioritize one gender over another gender in the context of social situations and professional circumstances. One can either be inclined towards a specific gender or influenced against the specific gender. 
Illustration 1: A man might be biased contrary to the woman co-employees and that is why would rather work alongside the other men. This biasness results in gender discrimination if that man serves as a managing authority or the boss of that company.

Illustration 2: A man might be biased towards the woman nursing staff and that is why think that he serves well and even enhanced compassionate treatment to the patients as compared to the other males nursing staff.

In any organization, the employees are shielded by the help of laws, not in favour of gender discrimination, and are guarded against those who have a superiority complex and use their employees as their prey, because of their work status (Korburtay et al., 2020).

According to the laws about the issue of gender discrimination, set by the legislative board of Pakistan's National Assembly, it should be noted that unsuitable attitude must be reported immediately to the managing department of the Human resource sector, to the police department, and to the colleagues as well (Cholil \& Sudirman, 2019).

Right Away, in accordance with my reflection of thoughts, there is the bold, vocal, and transparent opinion about gender discrimination as well as gender biasness. Gender biases are the inclination in the direction of a specific gender (meant for any action, circumstance) also, in most cases gender discrimination is the consequence of the communal or the personal gender biasness, intentional or unintentional. In case I state that the nursing staff of the hospital has done great work in treating my injury (True \& Eddyono, 2021). Many among the people would readily suppose that I might talk about some woman nursing staff. This is referred to as gender biasness; all of us are unconsciously biased because of our assumptions that the profession of nurse is solely designated to women. So, in case the patient refuses to get her wound dressed by the male nursing staff, it would be referred to as gender discrimination. Now the difference between gender biasness and gender discrimination has been made clear so we will point our next discussion wholly on gender discrimination.

\section{Defining Gender Discrimination}

The Oxford definition of 'Gender Discrimination' refers to gender disparity, which corresponds to a public mechanism in which individuals are classified differentially and at the unfair in identical conditions on the grounds of gender (Griffin, 2017). However, the Cambridge definition demonstrates gender discrimination as a condition where an individual is served differently based on their sex (Combley et al., 2011).

\section{Concept of Gender according to the Islamic teachings}

Holy Quran, which is the major foundation of Shariah, specifies that both men, as well as women, are spiritually equal. The Qur'an 4:124 states:

\section{"If any do deeds of righteousness, be they male or female and have faith, they will enter Heaven, and not the least injustice will be done to them." (Quran, 4:124).}

However, in many policies of Muslim organizations this principle of equity is never expressed (Saiful \& Fendri, 2020 , pp. 197-200). Stereotypes for women have not been defined by Quran (Supriyadi et al., 2019, pp. 91-110). Furthermore, social norms emerge in Islamic culture, mainly since distinct privileges and social obligations are often assigned to men and women. Women are morally prohibited from exercising such liberties in many Islamic nations (Ali \& Syed, 2017, pp. 472-486).

In Surat Nisa verse it is quite obvious:

“O mankind! Reverence your Guardian-Lord, who created you from a single person, created, of like nature, his mate, and from them twain scattered (like seeds) countless men and women; fear Allah, through whom ye demand your mutual (rights), and (reverence) the wombs (that bore you): for Allah ever watches over you". (Quran 4:1).

This reveals that no sex is superior to another. Ibn Abbas states that each person has the strength of a common human and divine essence. The two sexes are made from one soul. Ibn Abbas further said that Allah created humanity from one single human being, from whom He formed his companion, and from them several individuals both men as well as women scattered globally (Samsuri et al., 2018).

Islam raises women's inferior existence and gives women full equality. The exceptional social justice guaranteed to them through a religious belief of monotheism as described in the Quran shows the fair treatment of females in Islam. The content of said verse suggested that particular sexuality over another is not characterized in the main Islamic context as evidence of gender unbiasedness and justice (Rahbari, 2021).

Till now, one can never bring any Islamic records, whether they are from Qur'an or Hadith, which claim that women must remain at home or cannot do stuff outside their house. Allah, meanwhile, has granted both women and men relatively similar universal obligations. As mentioned in verse 71 of Surat Tawbah (Forgiveness), Allah has assigned the following six duties to both sexes: 
"The Believers, men, and women are protectors, one of another: they enjoin what is just and forbid what is evil: they observe regular prayers, practise regular charity, and obey Allah and His Messenger. On them will Allah pour His Mercy: for Allah is exalted in power, Wise”. (Quran, 9;71).

Abdullah Ibn-e-Abbas states that Islam specifies similar duties for men and women, and therefore Allah has confirmed through this verse that He has blessed those who carry out these tasks, whether men or women. Due to their sexual identity, women also aren't spared from such duties and commitments (Cholil, 2017).

The context of the Qur'an (verse 34 of Surat Nisa) states that men are accountable for women's matters and women they concern for are following:

"Men are the protectors and maintainers of women, because Allah has given the one more (strength) than the other, and because they support them from their means". (Quran, 4:34)

Ibn Abbas identifies that men have no freedom to act arrogantly in their treatment of women and to disregard their status or to limit their status inside the household. Their power is that whether they defend women or provide them safety. These safeguards and facilities should indeed be consulted and sincerely respected (Brenner, 2018). Sheik Salman AlOadah thinks it means that men have to provide for their wives (under their accountability), secure her, safeguard her dignity, and meet her religious and material needs (Pramesi, 2021). The explanations for this are, as displayed in the verse,

“...because of what Allah has preferred one with over the other and because of what they spend to support them from their wealth...” (Quran, 4:34).

In other words, Islam considers men and women as per their innate distinctions, and hence men's desires are intrinsic in them and vice versa. Social justice would not involve uniformity. Equity among both men and women should not involve absolute similarity because of the intrinsic disparities between the two sexes (Alikarami, 2019).

Women have many rights that are stripped of by guy. 'Women as discussed above has the right to their men's full support and protection. Women have no household costs to deal with or divide with their spouses. As a parent, for instance, in the vision of God, a woman deserves greater dignity and praise. The love for parents (particularly mothers) is after the love for Allah and His Messenger (PBUH) (Islamy, 2020).

Islam has given women the right to decide who they want to marry. Marriage is a contract with Islam. Women are completely entitled to approve the marriage proposal or refuse it. The approval of women shall be a necessary condition for the legitimacy of the marriage as per the sayings of Muhammad (PBUH). The Holy Prophet once said:

"A previously married woman cannot be married until her order is sought and a virgin cannot be married until her permission is sought”.

They asked: How do they know about her consent? He responded: "If she keeps silence" (Al Bukhari and Muslim). In another Hadith, Ibn Abbas testified that a girl filed a complaint against her father before the Prophet (PBUH) that she is being forced to get married despite her resistance, to elevate the public prestige of her father. Prophet Mohammad (PBUH) asked her to either accept the marriage or reject it; the girl replied: “O Messenger of Allah! I accept my father's command; however, I desired that women understand that their parents cannot command them to marry someone against their will" (Ahmad and Ibn Majah and others) (Ibnouf, 2015).

In Islam, women have much right to free speech as men. Women's views are put into the account and so are not dismissed merely because they belong to women. In Qur'an, women have been told that they can openly share their thoughts yet also argue and engage themselves in serious debates with Muhammad (PBUH) himself (Mirshekari \& Ghasemi, 2019).

The symbolic statements of Muhammad (PBUH) concentrate on respecting women, treat them with just and compassion. The Prophet Muhammad (PBUH) told Abu Huraira (R.A) that:

“I commend you to be kind to women”. (related by Muslim, Al Bukhari, and others) (Nawawi, 2014).

Mohammad (PBUH) helped his spouses in house chores which reveals that no deterioration is related to the execution of preparing food, sweeping, laundry, etc.

When Allah proclaimed that Heaven was beneath the mothers' feet, Muhammad (PBUH) also addressed the mother's dignity. A woman has the entitlement of $3 / 4$ of the respect and affection of her kids with $1 / 4$ for their fathers. Abu Huraira (R.A) narrated that a man came over to Prophet (PBUH) and asked: O Messenger of Allah, who amongst the humans is highly eligible of my virtuous company? The Prophet (PBUH) replied: "Your mother". The man asked that who next: The Prophet responded again: "Your mother". The man again requested, and who next? After that, the Prophet (PBUH) said: "Your father". (Al Bukhari) (Nawawi, 2014).

\section{METHODOLOGY}

Analytical and critical evaluation techniques have been used in executing this research study. Ongoing gender-based 
discrimination in societies of Muslim worlds has been analysed through various sources including published journal articles, news articles, and books, etc. These analytical studies are then critically evaluated in the light of the Holy Quran and Sunnah as primary study resources.

\section{FINDINGS AND DISCUSSION}

\section{Findings}

Here are some findings of this study:

- In the Islamic perspective, no gender is superior to another gender.

- Women of the Pakistani society have been made deprived of acquiring education, in some regions, they are not allowed to even get basic knowledge.

- At workplaces, people are facing gender biases.

- Pakistan has passed the bill for the protection of women's rights.

- The United Nations (UN), World Bank, and Organisation for Economic Cooperation and Development (OECD) in developed nations have focused extensively on gender discrimination at a global platform. The factors and consequences of gender bias differ greatly, as do strategies for addressing this issue. Gender discrimination can be better clarified by patriarchy processes. Inequality usually occurs in this way, when both sexes are exposed to a biased treatment on grounds of sexual preference.

- Gender bias happens as both genders are part of different aspects of social mindset. Sexism often plays its part in communication and unfair treatment even within business sector. Usually, men hold public offices in the economic environment. Owing to the interest or desire of men, since they have common traits, men in such offices of leadership are often more eager to recruit or employ men, thereby oppressing women.

- Recently, European Union Human Rights Commission published a study on gender inequality by re-defining the gender system, describing that, regardless of relationship status, any separation, omission, or limitation based on gender with the consequence or intent of degrading and annulling women's acknowledgment of happiness or practice in economical, societal, traditional, or other fields comes under gender discrimination.

\section{DISCUSSION}

Concerning Gender Discrimination in the Pakistani culture, Pakistan has been the 2nd worst nation in the globe regarding gender equity and ranks 148 out of 149 in the 'Global Gender Gap Index' during 2018 as per the latest study published by the WEF. After reviewing this survey and a few others it is highly deceitful that a nation is predominantly more than 90 percent Muslims, although very low in respect to gender equality. Pakistan has narrowed 55 $\%$ of its ultimate gender gap relative to the highest-ranking Bangladesh (72\%) and Sri Lanka (68\%) (Ahmed, 2018).

The annual survey of the Geneva-based agency, which dealt with gender inequalities in 149 nations in four fields: literacy, healthcare, financial chance, and community development. The strategic plan of Pakistan shows that Pakistan listed 146th in respect to economic development; and 145th in potential in wellbeing. The state was ranked 97 when it came to democratic representation. The study found out that the populace of Pakistan grew at $1.93 \%$ annually (Kaffenberger \& Pritchett, 2020).

The study shows a smaller volume of women as compared to men who are working, showing that the effect of technology on the typical employment of women appeared excessive (Masitoh \& Pramesti, 2020).

Women were substantially marginalized in rapidly growing fields requiring scientific, technical, software, and mathematical skills, as observed by WEF. It denounced the notably impaired role of women in the discipline of artificial intelligence, where they constituted just $22 \%$ of the total personnel (Umar \& Asghar, 2018).

With recent trends in mind, it claimed that among 106 nations covering since its first survey, the total gender disparity will narrow over the next century. It seems that the financial and social component for advancement, which would last for another century, is the most complicated gender disparities to address (Kiram, 2020).

Maria Umar, President of Women's Digital League, during a talk with Pakistan Today, identified that women's agencies have recently recognized that women have not been adequately treated at the higher leadership ranks, but there is no specific attempt to change the scenario. "Gender parity could only be accomplished through the integration of women and men. The major issue is that people speak about equality of women, however, they don't know that during this process more women have to be granted access to conventions, workshops, etc." she added. Maria stated that this is among the tangible measures to improve gender equity in this course. She said, "More representation in all aspects means more exposure and might hopefully lead to equity (yder, 2018). 
Gender disparity is the consequence of chronic prejudice against a particular community of individuals on the grounds of sexuality which expresses itself distinctly in terms of ethnicity, community, ideology, continent, and financial status. It is often viewed as a causative component in abuse towards women (Pervez \& Iraqi, 2018; Showunmi \& Kaparou, 2017).

Although gender inequality exists in both sexes in particular cases, bias towards women is a deep-seated worldwide concern. Abuse and brutality towards women had never been taking notice of in the Islamic Republic of Pakistan. However, in Afghanistan, women are being punished if they attend any educational institute (Ahmad \& Khan, 2020).

Here are some recommendations in the light of the study:

- The Pakistani government is expected to take appropriate action to ensure the continuity of gender equity facilities, programs, and social security, and empowering tribal women.

- It is time to eradicate the inequality between men and women, and also violence and racial oppression against women. Without the contribution from the 50\% proportion of women, the nation will not step in the direction of growth and development.

- Women represent $50 \%$ of the nation's populace and this is a perfect chance for Imran Khan's innovative leadership to sensitize women to pursue their primary role in the country's development and growth.

- It is indeed a reality that the recent democratic representative has drawn up successful policies for the advancement of women across the world, and eligible women will not find employment in each aspect of life nowadays.

- Women leadership should be effective in raising the social and financial status of the $50 \%$ of the populace, both in industrial and remote areas of the state.

- All entities seeking to empower women have to cross the disparity between wealthy and poor women to promote and contribute to making all women worthy players in the social structure.

- The central Government's vital measures to ensure the welfare of women in the factories, households, and technical educational institutions for women are being promoted.

- Ensure that attempts are being taken to facilitate legal rights for women.

- Numerous political agencies and non-governmental entities should hold numerous seminars and meetings to address women's concerns.

\section{CONCLUSION}

From the above-mentioned discussion, it is concluded that sexism against men and women is a worldwide important concern. While the volume reduces dramatically, it persists and each day induces many people to bear the influence. However, there are explanations for inequality based on sexuality that cannot be readily resolved. There are several grounds to believe, though, that gender discrimination is avoided in the long term as a result of awareness and positive thinking. Then citizens will ideally reside in dignity regardless of gender.

In daily life, there are significant socio-economic disparities and bigotry against minority groups. How disparity among all different classes of society persists could be demonstrated. Minority groups strive to be like those groups created by the society (Yasin \& Aslam, 2018). The way schooling is unbalanced, income disparities, and the ongoing cycle of unemployment make this evident. Numerous individuals have raised their voices to explain these challenges. The disabled women are less vulnerable to domestic abuse as well as to sexual harassment than the disabled men or women with no disorders, are less likely to be in decent jobs. Trans-genders or distinct individuals may be compelled, until they have access to care, at work and also in social environments, to disguise their sexual identity. Mental disorders, verbal harassment, physical violence, cyber intimidation, and cultural isolation seem to be more inclined to arise. The central argument of all of this discussion concludes on this declaration from Malala Yousafzai: "I stand with freedom. Even I think women are stronger than men." (Malala Yousafzai on talk with Jon Stewart at a show).

\section{LIMITATION AND STUDY FORWARD}

Although, this study covers the Islam dimension and notions regarding gender discrimination and the prevalence of this issue in Pakistan. Still, the leading of gender discrimination towards human trafficking, and the smuggling of immigrants needs to be discussed, also, the Islamic perspective upon these criminal activities needs to be addressed comprehensively.

\section{ACKNOWLEDGEMENT}

I would like to thank my research fellows Abdul Rauf, Iram Sultana, and Muhammad Saeed for their support in the completion of this research article.

\section{AUTHORS CONTRIBUTION}

Dr. Syed Shahid Tirmizi has generated the main idea of the research, worked on research methodology, and developed 
the tool for data collection. Abdul Rauf has worked on a literature review and collected the data. Iram Sultana planned the data analysis and analysed the data and Muhammad Saeed has worked on the literature review.

\section{REFERENCES}

1. Ahmed, A. (2018). Pakistan among worst performers on gender equality: WEF. Daily dawn. December, 19.

2. Ahmad, A., \& Khan, R. N. (2020). Conflicting and Challenging Patriarchal and Liberal Feminist Ideologies and Norms in Afghanistan: Critical Stylistic Study of Khaled Hosseini's And the Mountains Echoed. Arab World English Journal (AWEJ), 11(2), 154-167. https://doi.org/10.24093/awej/vol11no2.11

3. Ali, F., \& Syed, J. (2017). From rhetoric to reality: A multilevel analysis of gender equality in Pakistani organizations. Gender, Work \& Organization, 24(5), 472-486. https://doi.org/10.1111/gwao.12160

4. Alikarami, L. (2019). Women and Equality in Iran: Law, Society and Activism. I.B. Tauris. https://doi.org/10 $.5040 / 9781788318853$

5. Bukhari, M. A. H. S., Gaho, M. G. M., \& Soomro, M. K. H. (2019). Gender inequality: Problems \& its solutions in Pakistan. The Government-Annual Research Journal of Political Science, 7(7).

6. Brenner, S. (2018). Islam and gender politics in late New Order Indonesia. Spirited Politics, 93-118. https://doi .org/10.7591/9781501719486-006

7. Cholil, M. (2017). Complexities in dealing with gender inequality: Muslim women and mosque-based social services in East Java Indonesia. Journal of Indonesian Islam,11(2), 459. https://doi.org/10.15 642/JIIS.2017.11.2.459-488

8. Cholil, M., \& Sudirman, S. (2019). Gender Equality in Islamic Family Law: Breaking the Chain of Domestic Violence to Achieve Harmonious Family. Kafaah: Journal of Gender Studies, 9(2), 131-146. https://doi.org/10 $.15548 / \mathrm{jk} . \mathrm{v} 9 \mathrm{i} 2.270$

9. Choudhry, A. N., Mutalib, R. A., \& Ismail, N. S. A. (2019). Socio-cultural factors affecting women economic empowerment in Pakistan: A situation analysis. International Journal of Academic Research in Business and Social Sciences, 9(5), 90-102. https://doi.org/10.6007/IJARBSS/v9-i5/5842

10. Combley, R. (2011). Cambridge Business English Dictionary. Cambridge University Press.

11. Griffin, G. (2017). A Dictionary of Gender Studies. Oxford University Press. https://doi.org/10.1093/acr ef/9780191834837.001.0001

12. Hyder, W. (2018, April 25). Pakistan at bottom in gender equality at work index. Pakistan Today. https://archive.pakistantoday.com.pk/2018/04/25/pakistan-at-bottom-in-gender-equality-at-work-index/

13. Ibnouf, F. O. (2015). The Gender Equality and Women's Human Rights in Islamic Texts (Quran and Hadith).

14. Islamy, A. (2020). Gender Mainstreaming in The Hermeneutics of Islamic Family Law. Al-Bayyinah Jurnal Hukum Islam, 4(1). https://doi.org/10.35673/al-bayyinah.v4i1.686

15. Kaffenberger, M., \& Pritchett, L. (2020). Aiming higher: Learning profiles and gender equality in 10 low-and middle-income countries. International Journal of Educational Development, 79, 102272. https://doi.org/10.1016/j.ijedudev.2020.102272

16. Kiram, M. Z. (2020). Achieving Gender Equality through Understanding; Rethinking and Rebuilding Peace. Rethinking and Rebuilding Peace (January 20, 2020). https://doi.org/10.2139/ssrn.3522622

17. Koburtay, T., Syed, J., \& Haloub, R. (2020). Implications of religion, culture, and legislation for gender equality at work: Qualitative insights from Jordan. Journal of Business Ethics, 164(3), 421-436. https://doi.or $\mathrm{g} / 10.1007 / \mathrm{s} 10551-018-4036-6$

18. Masitoh, D., \& Pramesti, F. A. (2020). Gender Inequality in Pakistan Caused by Domestic Factors and Conflict Resolving Based on CEDAW. Nation State Journal of International Studies, 3(2), 240-257. https://doi.org 110.24076/NSJIS.2020v3i2.241

19. Mirshekari, A., \& Ghasemi, R. (2019). The study of justice in determining women's rights in the family according to the Islamic legal system. Journal of Shariah Law Research, 4(2), 201-222.

20. Nawawi, I. (2014). Riyad As Salihin: The Gardens of the Righteous. Tughra Books.

21. Pervez, S., \& Iraqi, K. M. (2018). Gender Discrimination-Prevailing State in Pakistan. Pakistan Journal of Gender Studies, 16, 153-170. https://doi.org/10.46568/pjgs.v16i1.121

22. Pramesi, N. A. (2021). Implementation of Maqasid Syari'ah in the Concept of Reforming the Indonesian Marriage Law Based on Gender Equality: Study of the Counter Legal Draft Compilation of Islamic Law. International Journal of Advanced Research in Islamic and Humanities, 3(1), 1-10.

23. Rahbari, L. (2021). When gender turns right: racializing Islam and femonationalism in online political discourses in Belgium. Contemporary Politics, 27(1), 41-57. https://doi.org/10.1080/13569775.2020.1813950

24. Saiful, T., \& Fendri, A. (2020, March). Gender Equality Perspective and Women Position in Islam. In International Conference on Law, Governance and Islamic Society (ICOLGIS 2019) (pp. 197-200). Atlantis Press. https://doi.org/10.2991/assehr.k.200306.212

25. Samsuri, S., Mursidin, M., \& Mujahidin, M. (2018). Character Education Based on Gender Justice in The Islamic Perspective. Al-Hayat: Journal of Islamic Education, 2(2), 202-212.

26. Showunmi, V., \& Kaparou, M. (2017). The challenge of leadership: Ethnicity and gender among school leaders in England, Malaysia and Pakistan. Cultures of Educational Leadership, 95-119. https://doi.org/10.1057/978-1$\underline{137-58567-7 \quad 5}$ 
27. Supriyadi, T., Julia, J., \& Firdaus, E. (2019). The Problems of Gender Equality: A Reconstruction of Islamic Doctrine. Journal of Social Studies Education Research, 10(2), 91-110.

28. The Holy Quran (2006, July). Minhaj-ul-Quran Publications, Lahore, Pakistan

29. True, J., \& Eddyono, S. (2021). Preventing Violent Extremism-What Has Gender Got to Do With It? European Psychologist, 26(1), 55-67. https://doi.org/10.1027/1016-9040/a000434

30. Umar, M., \& Asghar, Z. (2018). SDG Index for Pakistan at Provincial Level. https://mpra.ub.unimuenchen.de/83997/

31. Yasin, S. A., \& Aslam, S. (2018). School Dropout of Rural Girls in Pakistan: Exploring the Role of Gender Discrimination. Journal of Research \& Reflections in Education (JRRE), 12(1). 